九州大学学術情報リポジトリ

Kyushu University Institutional Repository

\title{
Taxonomic Notes on Lasioglossum (Evylaeus) vulsum
}

Ebmer, Andreas Werner

Kirchenstraße 9, A-4048, Puchenau, Austria

Murao, Ryuki

Entomological Laboratory, Graduate School of Bioresource and Bioenvironmental Sciences, Kyushu University, Fukuoka

Tadaichi, Osamu

Entomological Laboratory, Faculty of Agriculture, Kyushu University, Fukuoka

https://doi.org/10.5109/2859

出版情報: ESAKIA. 46, pp.31-33，2006-06-30. Entomological Laboratory, Faculty of Agriculture， Kyushu University

バージョン :

権利関係 : 


\title{
Taxonomic Notes on Lasioglossum (Evylaeus) vulsum (Vachal, 1903) (Hymenoptera, Halictidae)
}

\author{
Andreas Werner Ebmer ${ }^{1)}$, Ryuki Murao ${ }^{2)}$ and Osamu Tadauchi ${ }^{3)}$ \\ 1) Kirchenstraße 9, A-4048, Puchenau, Austria \\ 2) Entomological Laboratory, Graduate School of Bioresource and Bioenvironmen- \\ tal Sciences, Kyushu University, Fukuoka, 812-8581 Japan \\ 3) Entomological Laboratory, Faculty of Agriculture, Kyushu University, Fukuoka, \\ 812-8581 Japan
}

\begin{abstract}
A synonymy of Lasioglossum (Evylaeus) vulsum (Vachal, 1903) with L. (E.) trispine (Vachal, 1903 ) is presented. This has been long overlooked and is reconfirmed in the present study. The species that has been identified as $L$. vulsum represents another taxon, and the species that has been identified as L. trispine is L. vulsum. Photographs and diagnosis of type specimen of L. vulsum are provided. Biological comments and geographical distribution are also given.
\end{abstract}

Key words: Hymenoptera, Halictidae, Halictinae, Lasioglossum (Evylaeus) vulsum.

\section{Introduction}

Vachal originally described both Halictus vulsus and H. trispinis in the same paper in 1903. The description of Halictus vulsus was based on a male specimen and that of $H$. trispinis on a female specimen. In the course of a collaborative study of Palaearctic Evylaeus, one of us, Ebmer examined the holotypes of $H$. vulsus and $H$. trispinis, which are preserved in the Muséum National d'Histoire Naturelle, Paris, France. It was noticed that the diagnostic characters of L. vulsum (=H. vulsus) were identical with those of male L. trispine ( $=H$. trispinis). Maeta (1966) studied the biology of L. trispine and obtained specimens of both sexes. As $H$. trispinis was described in the next page of H. vulsus in the same journal, the former is a junior synonym of the latter. Blüthgen (1926) had already reported this synonymy, but it has been overlooked. Lasioglossum vulsum and L. trispine have been treated as separate species by many researchers (Haneda, 1990; Ebmer, 1995; Goubara et al., 2002 etc.). In addition, Ebmer has reported L. vulsum as L. trispine in some papers (Ebmer, 1978a; 1978b; 1996). The species that has been identified as L. vulsum represents another taxon in our study, and the species that has been identified as L. trispine is the species L. vulsum.

In this paper, we reconfirm the synonymy of $L$. vulsum with $L$. trispine and provide a diagnosis of $L$. vulsum, including photographs of the type specimen, biological comments and geographical distribution.

The specimens examined were borrowed from the following institutions and personal collection, which are referred to in the text by the following abbreviations: $\mathbf{E L K U}=$ Entomological Laboratory, Faculty of Agriculture, Kyushu University, Fukuoka, Japan; SCMH= the late Dr. Shôichi F. Sakagami's Collection, Museum of Nature and Human Activities, Hyogo, Japan; OLLA= Oberösterreichischen Landesmuseums, Linz, Austria. Other specimens without abbreviations belong to a private collection (R. Murao), which kept temporarily at the Entomological Laboratory, Kyushu University, Fukuoka, Japan.

\section{Lasioglossum (Evylaeus) vulsum (Vachal, 1903)} (Fig. 1. A-G)

Halictus vulsus Vachal, 1903, Bull. Mus. Hist. (Paris), 9: 130 [male, Japan].

Lasioglossum (Evylaeus) vulsum: Ebmer, 1978a, Bonn. zool. Beitr., 29: 202-203; Ebmer, 1978b, Ann. Hist.nat. Mus. Nat. Hung., 70: 314; Ebmer, 1995, Linzer biol. Beitr., 27: 570 .

Halictus trispinis Vachal, 1903, Bull. Mus. Hist. (Paris), 9: 131 [female, Japan]; Blüthgen, 1926, Deutsch. ent. Zeitschr., 1926: 349 [Synonymy]. 


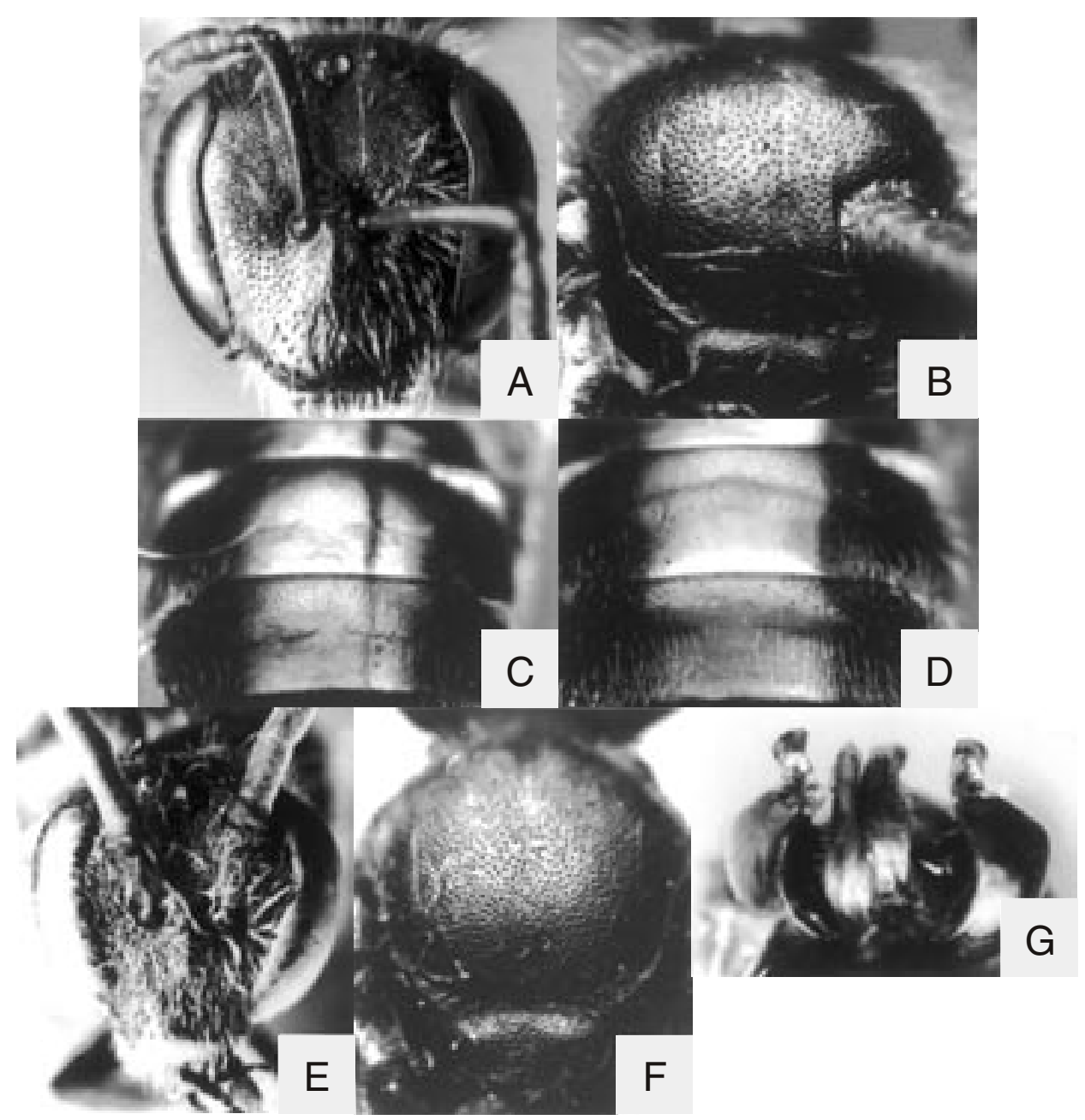

Fig. 1. A-G. Lasioglossum (Evylaeus) vulsum (Vachal). Female: A, head in frontal view; B, scutum; C, D, metasomal tergum third and fourth $(\mathrm{C}$ : the population of Japan. D: the population of Far East Russia). Male, holotype: E, head in frontal view; F, scutum; G, genitalia in upper view.

Lasioglossum (Evylaeus) trispine: Ebmer, 1995, Linzer biol. Beitr., 27: 571; Ebmer, 1996, Linzer biol. Beitr., 28: 280 .

\section{Diagnosis.}

Female. Face (Fig. 1. A) with sparse hairs. Head length:width $=1.70: 1.78$. Clypeus and supraclypeal area flat in lateral view, with fine punctures; on supraclypeal area 12-20 $\mu$ ø. Scutum (Fig. 1.B) with finer and scattered punctures 15-20 $\mu$; interspaces between punctures $0.5-1.5(0.5=1 / 2$ of the diameter of puncture $)$. The disc and posterior part of metasomal tergum 3: Japanese population has distinct cross-striation as in Fig. 1. C; Far East Russian (Primorsky) population has fine and obsolete cross-striation as in Fig. 1. D, and is more shiny than Japanese population.

Male. Lower half of clypeus yellow (Fig. 1. E.). Un- derside of antennae bright-ocher. Scutum (Fig. 1. F) with fine punctures, apically with more scattered punctures; interspace between punctures superficially reticulate and shiny. Gonostylus (Fig. 1. G) viewed from outside in the form of an anvil. The retrorse lobe slender; length of hairs similar to L. baleicum (Cockerell).

Notes. The separation of L. vulsum and L. trispine by Ebmer (1995) was a mistake.

Biology. This species is a solitary bee, begins to nest from about the beginning of March, and the nesting activity lasts till the middle of June for over-wintered females, which mated in early summer of the previous year (Maeta, 1966). However, Maeta could not identify the materials in his paper. Goubara et al. (2002) subsequently identified the species as L. trispine. As stated above, L. trispine is a synonym of $L$. vulsum. A member of our collaborative team, Murao, examined specimens 
of the species studied by Maeta (1966), and identified them as L. vulsum.

Distribution. Japan (Hokkaido, Honshu, Shikoku, Kyushu, Yaku-shima Is.), Far East Russia (Primorsky), Korean Peninsula (North).

Specimens examined. Holotype, male, Japan (Muséum national d'Histoire naturelle, Paris, France). [FAR EAST RUSSIA] 2 females, 70km, NW Plastun, 600-800m, Podnebesnyi pass, Primorsky, 18-26. vii. 1996 (A. Plutenko, OLLA). [KOREA] 1 male, Mt. Kumgang-san, North Korea, 28. vii. 1924 (K. Sato, ELKU). [JAPAN] we have examined 539 females and 401 males from the following localities in Japan: Hokkaido, Aomori, Iwate, Akita, Miyagi, Yamagata, Niigata, Tochigi, Kanagawa, Yamanashi, Nagano, Ishikawa, Fukui, Gifu, Mie, Nara, Wakayama, Osaka, Kyoto, Hyogo, Hiroshima, Yamaguchi, Tokushima, Ehime, Kochi, Fukuoka, Oita, Nagasaki, Kumamoto, Miyazaki, Kagoshima Prefs. Some of them are listed as follows. [Hokkaido] 1 female, Ashorobuto, Ashoro-gun, 13. vi. 1957 (M. Takahashi, ELKU); 2 males, Kitamoshiri, Hok. Uryu. Exp. Forest, 12. ix., 14. ix. 1969 (S. F. Sakagami \& H. Fukuda, SCMH). [Honshu] Aomori Pref.: 1 female and 1 male, Yunomata, Oohata-machi, Shimokita-hantou, 13. vii. 1956 (K. Morimoto, ELKU). Kanagawa Pref.: 1 female, Inokuchi, Nakai-machi, 8. v. 1975 (O. Tadauchi, ELKU). Ishikawa Pref.: 4 females, Osugitani-rindo, Shiramine-mura, 3. v. 2003 (K. Mitai). Yamaguchi Pref.: 4 females and 7 males, Toragasaki, Hagi-shi, 29. vi. 2004 (T. Sugimoto). [Shikoku] Ehime Pref.: 1 female, Tarumi, Matsuyama, 2-3. iv. 1952 (T. Edashige, ELKU). Kochi Pref.: 1 female, Nakamura-shi, 27. iv. 1957 (Y. Hirashima, ELKU). [Kyushu] Fukuoka Pref.: 95 females and 5 males, Kashii Fukuoka, 7. iv. 1958, 13. iv. 1958, 19. iv. 1958, 3. vi. 1958, 4. vi. 1958, 11. iii. 1959, 14. iii. 1959, 19. iii. 1959, 27. iii. 1959, 21. iv. 1959,24 . iv. 1959,29 . iv. 1959,10 . v. 1959,14 . v. 1959, 19. v. 1959, 28. v. 1959, 29. v. 1959, 3. iv. 1960, 8. iv. 1960 (Y. Maeta, ELKU). Miyazaki Pref.: 3 females,
Mt. Sobo, Gokasho, Takachiho, 27. iv. 2003 (R. Murao). Kagoshima Pref.: 2 females, Anbo, Yaku, Yaku-shima Is., 27. iv. 2005 (O. Tadauchi).

\section{Acknowledgements}

One of us, Murao thanks to Mr. F. Gusenleitner of Oberösterreichischen Landesmuseums, Linz, Austria for loan of specimens. This is a Contribution from the Entomological Laboratory, Faculty of Agriculture, Kyushu University, Fukuoka (Ser. 6, No. 25).

\section{References}

Blüthgen, P., 1926. Beiträge zur Synoymie der Bienengattung Halictus Latr. V. (Hym. Apid.). Deutsch. Ent. Zeitschr., 1926: 348-352.

Ebmer, A. W., 1978a. Die Halictidae der Mandschurei (Apoidea, Hymenoptera). Bonn. Zool. Beitr., 29: 183-221.

Ebmer, A. W., 1978b. Die Bienen der Gattungen Halictus Latr., Lasioglossum Curt. und Dufourea Lep. (Hymenoptera, Halictidae) aus Korea. Ann. Hist.-nat. Mus. Nat. Hung., 70: 307-319.

Ebmer, A. W., 1995. Asiatische Halictidae, 3. Die Artengruppe der Lasioglossum carinate-Evylaeus (Insecta: Hymenoptera: Apoidea: Halictidae: Halictinae). Linzer Biol. Beitr., 27: 525-652.

Ebmer, A. W., 1996. Asiatische Halictidae, 5. Daten zur Aculeaten-Fauna der Ussuri-Region unter Berücksichtigung der angrenzenden Gebiete (Insecta: Hymenoptera: Apoidea: Halictidae: Halictinae). Linzer Biol. Beitr., 28: 261-304.

Goubara, M., Y. Sugimoto, R. Miyanaga \& Y. Maeta, 2002. Some notes on the distributional records of sweat bees in Japan (Hymenoptera, Halictidae). Chugoku Kontyu, 15: 31-37. (In Japanese.)

Haneda, Y., 1990. On the Apoidea (Hymenoptera) of Fukui Prefecture, Japan (IV). Ent. J. Fukui, 7: 2-38. (In Japanese.)

Maeta, Y., 1966. Biological studies on the solitary bee, Lasioglossum sp. near fulvicorne (Kirby), (I) Environments of the nesting site and annual development of the colony. Kontyû, 34 (3): 223-231. (In Japanese.)

Vachal, J., 1903. Hyménoptères rapportés du Japon par M. Harmand., Mellifères. Bull. Mus. Hist. Nat. (Paris), 9: 129-132. 